\title{
Water quality and risk assessment of copper content in drinking water stored in copper container
}

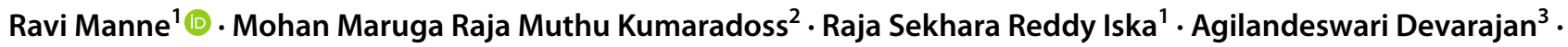 \\ Nageswararao Mekala ${ }^{1}$
}

Received: 20 July 2021 / Accepted: 15 November 2021 / Published online: 7 February 2022

(c) The Author(s) 2021

\begin{abstract}
In most developing countries, drinking water is still a serious challenge. Many water purification methods exist, but they are costly and out of reach for many people. Copper is an ancient metal that has been used from several thousands of years. Because of its antibacterial properties, ancient cultures held this metal in high regard. Copper vessels are still in use today for storing drinking water due to its ability to purify water. Therefore, the objective of this study was to evaluate the copper concentration in drinking water after storing in copper containers/bottle over different time periods with respect to copper safety levels. For this study, water is stored in a copper container up to $168 \mathrm{~h}$ and the water samples are collected at different intervals. The concentration of copper is analyzed in water samples using ICPMS, and it ranges from 0.009 to $0.823 \mathrm{mg} / \mathrm{L}$, which indicates as time increases simultaneously copper content also raises in the stored water. The higher copper content was detected at sample@168 h which was also well within the permissible limits of World Health Organization and United States Environmental Protection Agency.
\end{abstract}

Keywords Drinking water $\cdot$ Copper container/bottle $\cdot$ Safe limits $\cdot$ Copper toxicity

\begin{tabular}{ll}
\multicolumn{2}{l}{ Abbreviations } \\
$\begin{array}{ll}\text { USEPA } & \text { United States environmental protection agency } \\
\text { ICPMS } & \text { Inductively coupled plasma mass spectrometry } \\
\text { WHO } & \text { World health organization } \\
\text { APHA } & \text { American public health association } \\
\text { EPA } & \text { Environmental protection agency } \\
\text { EC } & \text { Electrical conductivity } \\
\text { TDS } & \text { Total dissolved solids } \\
\text { pH } & \text { Potential of hydrogen ion concentration }\end{array}$
\end{tabular}

Ravi Manne

ravimannemr@gmail.com

1 Environmental and Industrial Hygiene Services, Chemtex, Port Arthur, TX 77642, USA

2 Parul Institute of Pharmacy and Research, Parul University, Vadodara, Gujarat 391760, India

3 SynapsesAI India Private Limited, Indore, Madhya Pradesh, India

\section{Introduction}

Environmental pollution by various chemical elements including several toxic heavy metals is typically noticed as extremely increasing problem throughout the world (Adimalla and Qian 2021; Adimalla et al. 2020; Zhang et al. 2021). Specifically, this problem is very high in developing countries, where the drinking water quality is declining year by year. Especially, toxic chemical elements such as $\mathrm{Cu}$, $\mathrm{Hg}, \mathrm{Cd}, \mathrm{Pb}$ and $\mathrm{Cr}$ are the main pollutants which are highly released into the environment and also greatly affecting the environment and human health (Dong et al. 2020; Subba Rao et al. 2020; Adimalla and Qian 2019; Taiwo et al. 2020; Zhang et al. 2020). It is worth noting that these pollutants are released in different ways and reach into groundwater-table, eventually poisoning the drinking water. Particularly, copper contamination in drinking water has been identified and recognized to be among the global environmental pollution concern during the 1990s due to the introduction of various health based regulations (Fitzgerald 1995; IPCS 1999; USEPA 1985 1991; WHO 1998). Importantly, copper is an essential micronutrient serves as a fundamental component of human proteins and metalloenzymes (Underwood 1977). The United States Environmental Protection Agency 
(USEPA) has fixed $1.3 \mathrm{mg} / \mathrm{L}$ as the tolerable limit of copper ions in drinking water (USEPA 1985, 1991). This presumes that intake of copper at concentrations greater than the prescribed limit can cause acute health problems namely gastrointestinal disturbance, central nervous problems, mucosal irritation, Wilson's diseases, damage of liver and kidney, wide spread capillary damage, hepatic and renal damage etc. (Bashir et al. 2021; Gomaa et al. 2021; Kulkarni and Sharma 2017). However, lower concentration of copper ion in drinking water gives health benefits (Araya et al. 2001; Buchanan et al. 1994). Typically, drinking water contains copper, which is a naturally occurring ingredient. Stagnation of water in copper and copper alloy-containing pipes during the supply and distribution process to households allows leaching of copper and increases copper levels in the water. Copper leaching can be accelerated by water characteristics such as increased acidity, increased temperature, acidic nature of water, and decreased hardness (NRC 2000; Casper 2017). Moreover, copper ions can be accumulated by various sources such as industrialization, electronic waste treatment, urban waste treatment, and natural metal erosion, dissolution and also leaching to groundwater table. Such leached copper can be an effective dietary source in situations where dietary copper consumption is poor, but most people are concerned about the acute and chronic effects of copper toxicity in drinking water (Fitzgerald 1998).

Several techniques have been developed for copper removal, water treatment, purification and disinfection (Abedi Sarvestani and Aghasi 2019; Asokan et al. 2021; Bashir et al. 2021; Gomaa et al. 2021; Lytle et al. 2019; Sharma et al. 2020) that are expensive and not easy to carry and also unavailable for rural regions. Water purification was mentioned in ancient Ayurvedic texts by storing it in copper and silver pots. Interestingly, copper as a potential biocidal agent has been utilized as a disinfectant for many years due to their antimicrobial properties. Eventually, USEPA has listed copper as the first solid antimicrobial material. Fundamentally, when water is stored in copper containers, the metal infuses into the water, providing health benefits to the drinker. Thereby, in recent years, the usage of copper water containers has largely been increased worldwide. In other words, a great number people storing water in copper containers and habituated for drinking purposes. However, to the best of our knowledge, research on how much copper is released when water is stored in copper containers has not been reported. The current study was designed to explore the possibility of copper leaching capacity when water is stored in copper containers over period of time. Therefore, the primary objective of this study was to evaluate the copper concentration in water that was stored in copper containers. To fulfil this aim, drinking water was collected from drinking water tap and stored in copper vessels/containers. In addition, copper content of the collected water was assessed at different time intervals to test whether the quality of drinking water complies with the international guidelines for drinking purposes, and also discussed possible health risks. The findings of this study would be helpful in safeguarding the lives and also providing baseline scientific information about the water that was stored in copper containers.

\section{Materials and methods}

\section{Sample collection and analysis}

The sampling strategy, that is, initially water sample was collected from the drinking water tap and stored in $1000 \mathrm{~mL}$ capacity copper containers after methodically rinsed with distilled water (APHA 2012). This water sample was collected from the drinking water tap which is basically used for drinking purposes at $8.00 \mathrm{pm}$ CST, on Dec-2020. And about $120 \mathrm{~mL}$ of first sample was taken after $12 \mathrm{~h}$ period from the time frame water is collected into copper container and the sample was named as sample@12 h. Similarly, rest of the five samples were taken at the time intervals of $24 \mathrm{~h}$, $48 \mathrm{~h}, 72 \mathrm{~h}, 96 \mathrm{~h}$, and $168 \mathrm{~h}$ at $8 \mathrm{am}$ CST on the respective days, and they were named as sample@24 h, sample@48 h, sample@72 h,sample@96 h and sample@168 h, respectively. Finally, all these samples were stored at $4{ }^{\circ} \mathrm{C}$ and chemical analysis of copper concentrations was performed by using a Agilent 7900 inductively coupled plasma mass spectrometry (ICPMS) using EPA method 200.8. In addition, the basic water quality parameters such as $\mathrm{pH}$, electrical conductivity (EC) and total dissolved solids (TDS) were performed for all collected water samples from copper container following the standard methods of American Public Health Association (APHA 2012). The $\mathrm{pH}$ of the collected water samples was measured by using a $\mathrm{pH}$ meter (Thermo Scientific ORION Star A211, USA). The $\mathrm{pH}$ meter was calibrated with three calibration standards $(\mathrm{pH} 4.0,7.0$, $10.0)$ prior to the measuring of water samples. The EC of the water samples was measured using an electrical conductivity meter ((Thermo Scientific ORION Star A215, USA). The meter was calibrated with known conductivity 3 point calibration standards. The determination of TDS in samples was performed according to the Standard method (SM 2540 C). A fixed volume of water samples was filtered through TSS fiber filter into a pre-weighed glass beaker; the filtrate was heated in oven at $180{ }^{\circ} \mathrm{C}$ until all the water was completely evaporated. The remaining mass of the residue represents the amount of TDS in a sample. Pictorial form of methodology is visibly depicted in Fig. 1 and it shows the details of sample collections, duration of time, and analysis. 


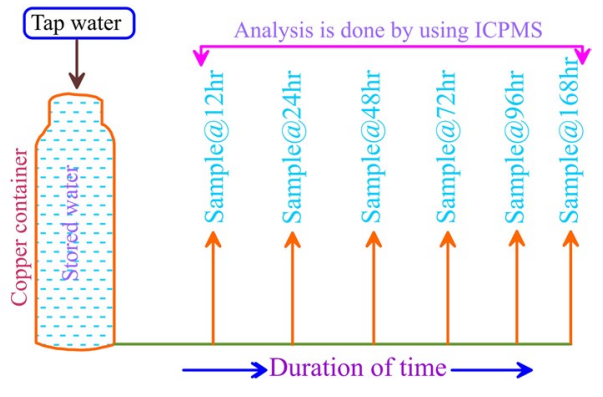

Fig. 1 Pictorial form of methodology (Raw water, stored water, samples collection, analysis)

\section{Sample digestion}

Added $2 \mathrm{~mL}$ of (1:1) nitric acid and $1.0 \mathrm{~mL}$ of (1:1) hydrochloric acid to all $100 \mathrm{~mL}$ digestion vails contain the $100 \mathrm{~mL}$ of the above collected samples. The digestion vails were placed on the hot block for sample evaporation. The hot block was adjusted earlier to a temperature of approximately but no more than $85^{\circ} \mathrm{C}$. Volume of the sample's aliquot was reduced to about $20 \mathrm{~mL}$ by slowly heating at $85^{\circ} \mathrm{C}$. This step took around $2 \mathrm{~h}$ for $100 \mathrm{~mL}$ aliquot with rapid increase in the rate of evaporation as the volume of the sample approached to $20 \mathrm{~mL}$, then the final volume was made up to $100 \mathrm{~mL}$ with deionized water and then these samples were filtered and finally analysis carried out by using a Agilent 7900 ICPMS. Standards preparation, instrument specification and calibration are clearly listed in Tables S1 and S2, respectively.

\section{Results}

\section{Hydrochemistry of the basic physicochemical parameters}

The measured concentrations of the most essential physicochemical parameters including $\mathrm{pH}, \mathrm{EC}$, and TDS of the water samples are presented in Table 1 . The $\mathrm{pH}$ values of water samples are found to be in the range between 7.02 and 7.16 with a mean of 7.07 (Table 1), which indicates that all collected water samples are in a neutral condition. Moreover, results clearly designate that $\mathrm{pH}$ values of all collected water samples are within the acceptable limit of 6.5-8.5 prescribed for drinking purpose (WHO 1993) and $\mathrm{pH}$ distribution is depicted in Fig. 2. The measured concentration of EC varies from 161 to $188.2 \mu \mathrm{S} / \mathrm{cm}$ with an average of $182.67 \mu \mathrm{S} / \mathrm{cm}$. The distribution of EC is shown in Fig. 2. In all collected water samples, the concentration of TDS is in between 79.1 and $94.5 \mathrm{mg} / \mathrm{L}$, and its average is $90.01 \mathrm{mg} / \mathrm{L}$ (Table 1). It indicates that concentration of TDS is within the allowable limit of $500 \mathrm{mg} / \mathrm{L}$ (Fig. 2).
Table 1 Results of copper concentrations, $\mathrm{pH}$, EC and TDS in water samples stored in copper container

\begin{tabular}{lllll}
\hline $\begin{array}{l}\text { Samples/time in } \\
\text { hours }\end{array}$ & $\mathrm{pH}$ & $\mathrm{EC}(\mu \mathrm{S} / \mathrm{cm})$ & $\mathrm{TDS}(\mathrm{mg} / \mathrm{L})$ & $\begin{array}{l}\text { Copper } \\
\text { concentration } \\
(\mathrm{mg} / \mathrm{L})\end{array}$ \\
\hline Raw water/0 & 7.02 & 161.0 & 79.1 & 0.009 \\
Sample@12 h/12 & 6.97 & 185.4 & 86.7 & 0.327 \\
Sample@24 h/24 & 7.16 & 185.1 & 94.27 & 0.482 \\
Sample@ 48 h/48 & 7.09 & 185.9 & 91.05 & 0.519 \\
Sample@72 h/72 & 7.06 & 186.2 & 91.22 & 0.521 \\
Sample@96 h/96 & 7.12 & 186.9 & 93.2 & 0.710 \\
$\begin{array}{c}\text { Sam- } \\
\text { ple@168 h/168 }\end{array}$ & 7.09 & 188.2 & 94.5 & 0.813 \\
\hline
\end{tabular}

\section{Concentration of copper}

Before presenting the chemical analysis of copper in drinking water, using ICPMS, it is also crucial to ensure the accuracy of analysis and also calibration standards of instrument. This information typically supports into two different ways, the first is (1) to distinguish the instrument response and capability of generate the analysis results, and (2) to confirm the precision of obtained analysis using calibrated instrument. Table 2 evidently shows the calibration standards of instrument, results of obtained value and true values. Specifically, the quality of the analysis is also confirmed by initial calibration and laboratory blanks which are evidently demonstrated in Table 2. Finally, calibration curve of the copper was generated which is depicted in Fig. 3. It is worth noting from Fig. 3 that the quantified correlation coefficient and relative percentage error were 1.00 and $15.8 \%$, respectively, and also indicates that obtained analytical results are true.

The results of copper concentration in drinking water of the present experiment are presented in Table 1. As can be seen from Table 1, the concentration of copper in rawdrinking water sample (before storing the water in copper container and named as sample@0 h) was observed at very low concentration $0.009 \mathrm{mg} / \mathrm{L}$. Several studies reported that low copper concentration is found in public drinking water supply (Araya et al. 2003, 2001). In other words, copper concentration is very nominal in drinking water. According to WHO (1993) and USEPA (1994) standards, water is unsuitable for drinking purposes when the copper contents in water are greater than 2.0 and $1.3 \mathrm{mg} / \mathrm{L}$, respectively. However, as discussed above, in this study the copper content was extensively examined after storing the drinking water in a copper containers/bottles at different time intervals such as $12 \mathrm{~h}$, $24 \mathrm{~h}, 48 \mathrm{~h}, 72 \mathrm{~h}, 96 \mathrm{~h}$ and $168 \mathrm{~h}$. Interestingly, the first-draw copper concentration (after 12 h's static period in copper container; sample@12 h) was recorded at lowest $0.327 \mathrm{mg} / \mathrm{L}$ (Table 1). Results also indicated that lowest $(0.327 \mathrm{mg} / \mathrm{L})$ and highest $(0.813 \mathrm{mg} / \mathrm{L})$ copper concentrations were 


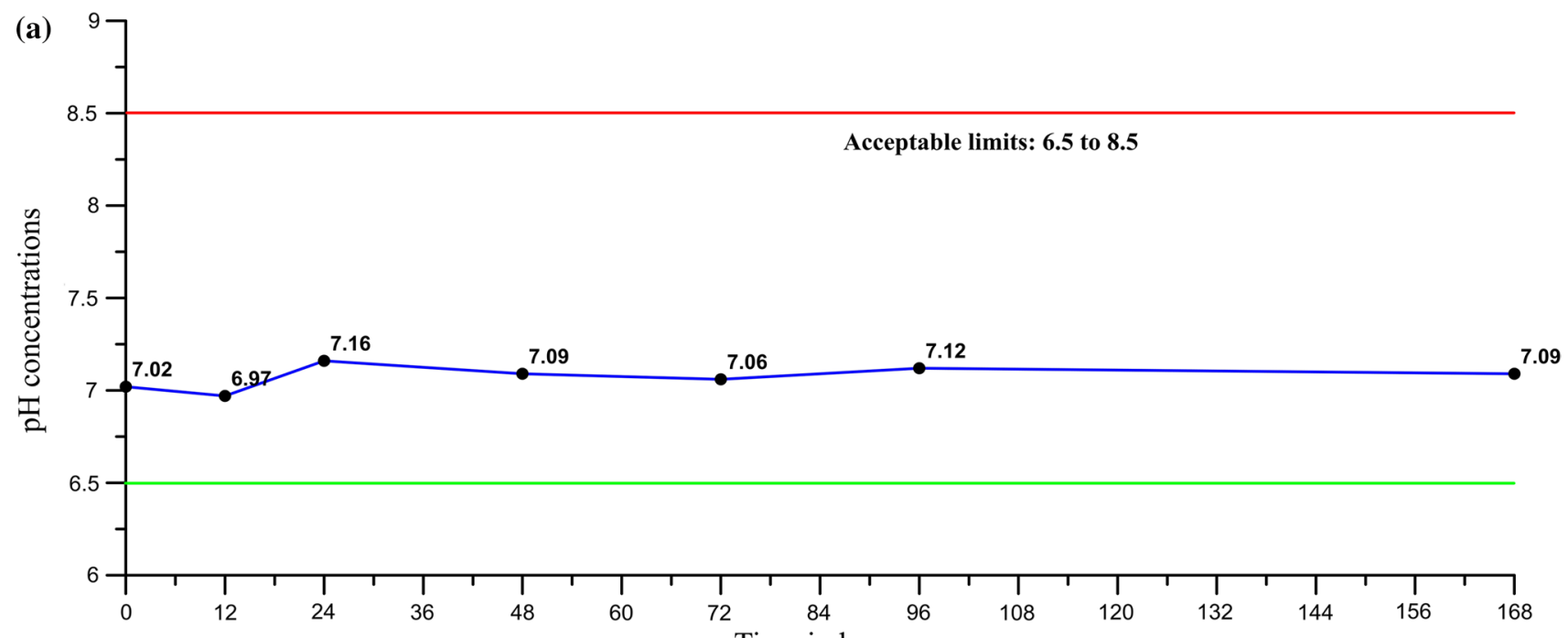

(b)

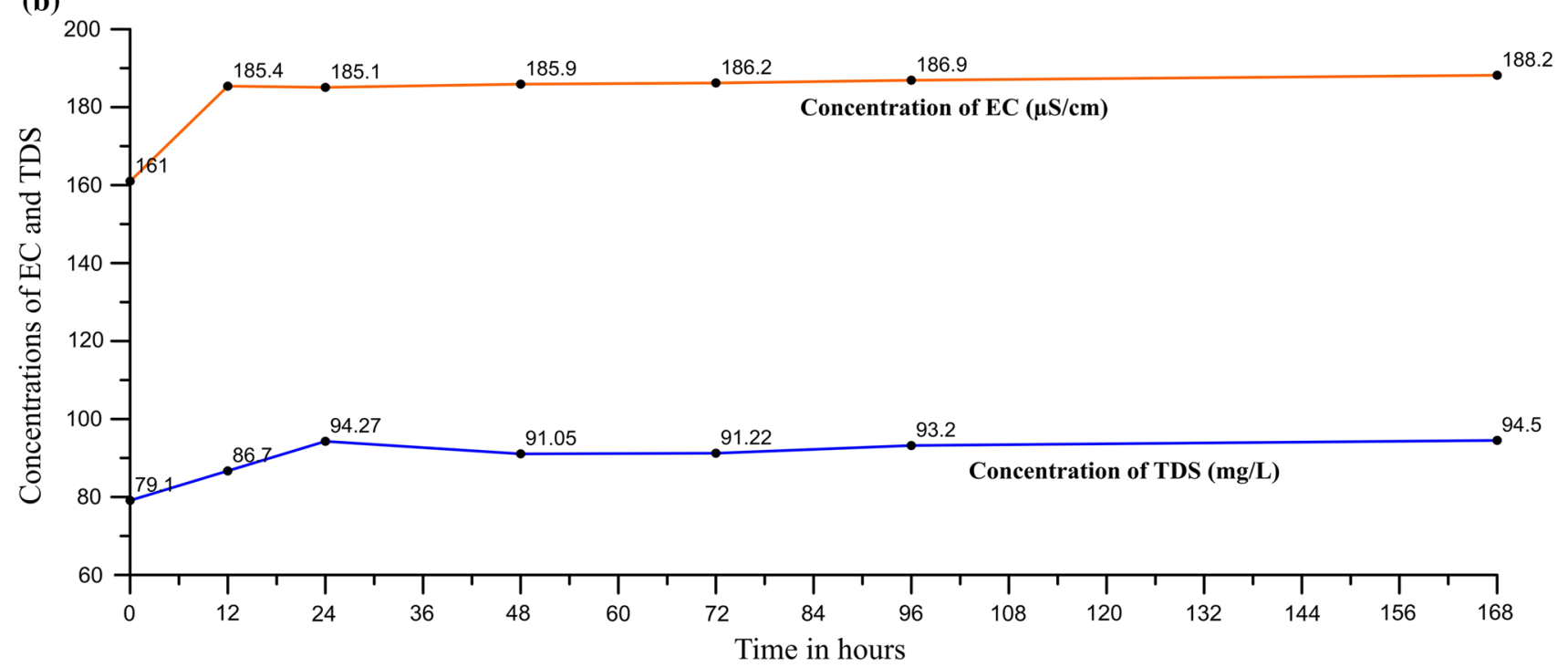

Fig. 2 Distribution of a pH versus time in hours, and $\mathbf{b}$ EC and TDS versus time in hours. The water samples were stored in copper containers, and measured $\mathrm{pH}, \mathrm{EC}$, and TDS in different time intervals

Table 2 Summary results of calibration standards, and quality control of analysis

\begin{tabular}{lll}
\hline Standard/sample & Obtained value $(\mathrm{mg} / \mathrm{L})$ & True value $(\mathrm{mg} / \mathrm{L})$ \\
\hline ICB (initial calibration blank) & -0.00008 & $0.00(1: 1 \mathrm{HNO})$ \\
Cal 2 & 0.001 & 0.002 \\
Cal 3 & 0.022 & 0.020 \\
Cal 4 & 0.501 & 0.500 \\
Cal 5 & 0.747 & 0.750 \\
Cal 6 & 1.002 & 1.000 \\
ICV (initial calibration verification) & 0.115 & 0.100 \\
MB (method blank) & -0.000076 & $0.00(1: 1 \mathrm{HNO})$ \\
LCS (laboratory blank) & 0.0043 & 0.005
\end{tabular}




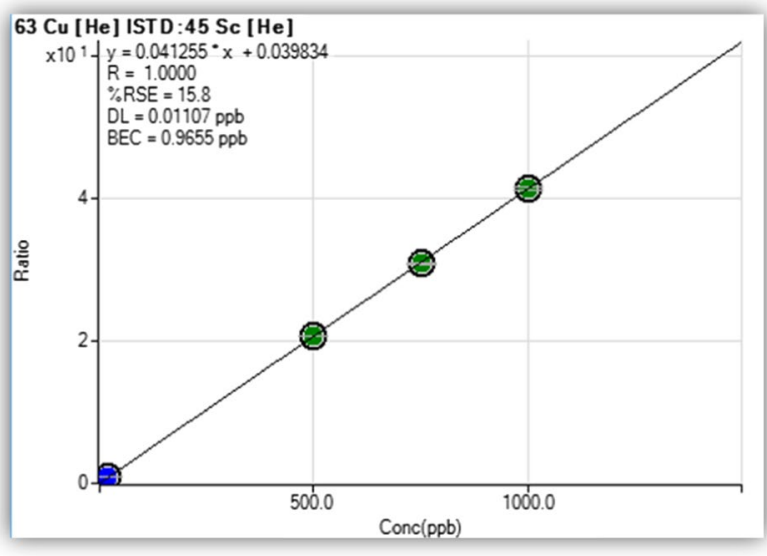

Fig. 3 Graph of copper calibration curve

observed in the sample@12 h and sample@168 h at the 12 and $168 \mathrm{~h}$ static periods, respectively. From this study, it is clear that trend of leaching copper concentration in water is progressively increasing as time increases, and the rising trend of copper concentration is evidently seen in Fig. 4 and Table 1. Generally speaking, the measured copper concentrations are within the guideline values recommended by both, WHO and USPEA for drinking purposes (WHO 1993; USEPA 1994). This experimental study basically suggests that the copper concentration is gradually increasing when water is stored in copper containers. Moreover, the present study evidently articulates that leaching of copper from the copper container is independent on the $\mathrm{pH}$ nature of the raw water. In both acidic and alkaline conditions leaching of copper from copper container increased with time. Moreover, it is also observed from this study, concentrations of EC and TDS demonstrated no significant corrections with the copper values (Table 1). In other words, EC and TDS values have no direct influence on concentration of copper when time increases.

\section{Discussion}

\section{Sources of copper}

\section{Through water distribution pipes}

Copper is available in the environment in different states and complexes. Solubility of copper is affected by the form in which it is present. Form of the copper present in food is different from that of water. Copper is usually complexed with inorganic ligands or adsorbed to insoluble particles (Florence et al. 1992). A small amount of copper is present in drinking water (Abedi Sarvestani and Aghasi 2019; Araya et al. 2001). Copper can be released into environment due to several human activities, especially into land and mining operations (Abedi Sarvestani and Aghasi 2019; Taylor et al. 2020). In addition, release of copper into water is due to soil weathering, discharge of industrial waste into water, sewage treatment plants, and antifouling paints (IPCS 1998). Water distribution is one of the reasons for increase of copper content in water. Pipes and plumbing fixtures are mostly made of copper in many countries which are used to distribute water, which could leach copper into water in those pipelines. Copper leaching into water can be high due to the underlying conditions like acidic nature of water,

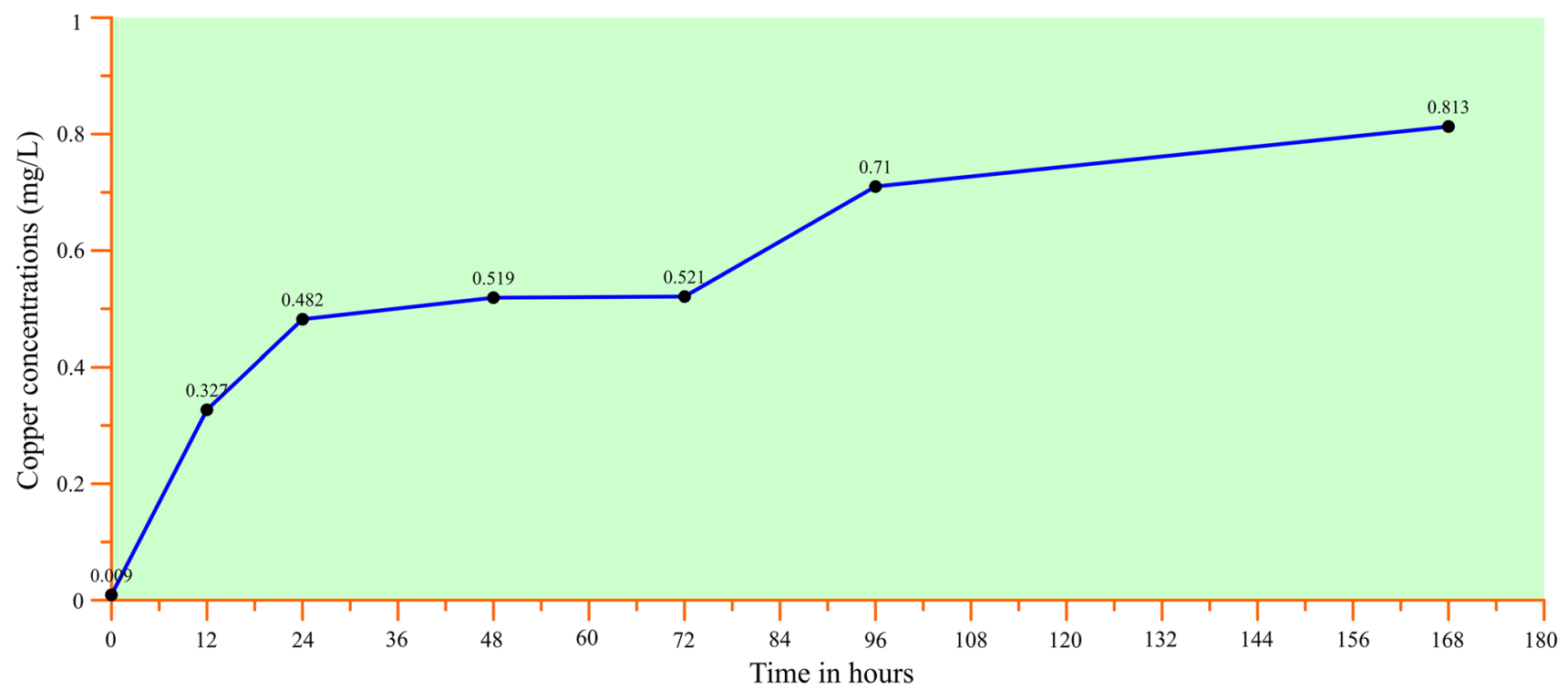

Fig. 4 Plot of copper concentration versus time in hours 
hard rock terrain, high temperature, and in household with comprehensively using of copper piping systems (USEPA 1994). Another important factor is the length of the time for which water is stagnant in these pipes before it's supplied to households. The present study also indicates that as time of stagnation increases, concentration of copper also increases to several $\mathrm{mg}$ (milligrams) per liter in the water.

\section{Through food and supplements}

Foods rich in copper include shellfish, organ meats, whole grain products, nuts and seeds, cereals made of wheat barn and chocolate (Collins et al. 2014; Prohaska et al. 2012) (Kulkarni and Sharma 2017). The United States Food and Drug Administration (FDA) has identified a list of copper content foods which are shown in Table 3. In addition, dietary supplements also contain copper directly, and sometimes copper in combination with other ingredients is available in multimineral/multivitamin products (National Institutes of Health 2018). It is widely understood that these supplements contain copper in different forms like cupric oxide, copper gluconate, cupric sulphate etc., and generally amounts of copper form these dietary supplements range from few micrograms to $15 \mathrm{mg}$ (which is 17 times more the DV for copper content) (National Institutes of Health 2018).
In the context of dietary, taking foods that contain high copper content through food and supplements, human body might be getting enough copper content already. In addition, it is apparently clear from this study that ingestion of water which was stored in copper containers for over a period of time (Table 1) can also accelerate the total copper concentration in the human body thereby higher possibility of increasing health risks. So, it is necessary to be mindful about the foods we eat, water we drink, procedures we follow for water purification which helps not to consume more amounts of copper.

\section{Copper toxicity}

It is well known, the copper is both an indispensable element and also poisonous at higher levels. As conferred above, exposure to higher levels of copper can elicit acute adverse effects to the liver and also engender the gastrointestinal symptoms like abdominal pain, cramps, nausea, diarrhea, and vomiting (Asokan et al. 2021; Buchanan et al. 1994; Fewtrell et al. 1996; Gotteland et al. 2001). Predominantly, several studies have reported ingestion of larger copper concentrations in drinking water have ensued in liver toxicosis mainly in infants and children (Abedi Sarvestani and Aghasi 2019; Gomaa et al. 2021; Taylor et al. 2020). In addition, the World Health Organization (WHO 1993) has detected
Table 3 Copper content of selected foods*

\begin{tabular}{|c|c|c|}
\hline Foods & Milligrams (mg) per serving & $\begin{array}{l}\text { Percent } \\
\text { daily } \\
\text { value }\end{array}$ \\
\hline Beef, liver, pan fried (3 ounces) & 12.400 & 1378 \\
\hline Oysters, eastern, wild, cooked, 3 ounces & 4.850 & 539 \\
\hline Baking chocolate, unsweetened, 1 ounces & 0.938 & 104 \\
\hline Potatoes, cooked, flesh and skin, 1 medium potato & 0.675 & 75 \\
\hline Mushrooms, shiitake, cooked, cut pieces, $1 / 2$ cup & 0.650 & 72 \\
\hline Cashew nuts, dry roasted, 1 ounces & 0.629 & 70 \\
\hline Crab, dungeness, cooked, 3 ounces & 0.624 & 69 \\
\hline Sunflower seed kernels, toasted, $1 / 4$ cup & 0.615 & 68 \\
\hline Turkey, giblets, simmered, 3 ounces & 0.588 & 65 \\
\hline Chocolate, dark, $70 \%-85 \%$ cacao solids, 1 ounces & 0.501 & 56 \\
\hline Tofu, raw, firm, $1 / 2$ cup & 0.476 & 53 \\
\hline Chickpeas, mature sees, $1 / 2$ cup & 0.289 & 32 \\
\hline Millet, cooked, 1 cup & 0.280 & 31 \\
\hline Salmon, Atlantic, wild, cooked, 3 ounces & 0.273 & 30 \\
\hline Pasta, whole wheat, cooked, 1 cup (not packed) & 0.263 & 29 \\
\hline Avocado, raw, $1 / 2$ cup & 0.219 & 24 \\
\hline Figs, dried, $1 / 2$ cup & 0.214 & 24 \\
\hline Spinach, boiled, drained, $1 / 2$ cup & 0.157 & 17 \\
\hline Asparagus, cooked, drained, $1 / 2$ cup & 0.149 & 17 \\
\hline
\end{tabular}

*This data was obtained from Food and Drug Administration of United States. The Food and Drug Administration of United States has developed Daily Values (DVs) in order to help the public compare the nutrient contents of foods and dietary supplements within the context of a total diet 
nausea as the principal symptom to assess serious effects associated with consumption of higher copper containing water. However, due to the size of the copper elements, most of the copper content is present in the bone and muscle. Copper is present in ceruloplasmin which is a protein made in the liver (Adkison 2012). Therefore, ceruloplasmin transports copper from liver into the blood stream and other parts of body (Adkison 2012; Harris 2019). Around half of the copper is excreted in the bile, and the other half present in the body is excreted through gastrointestinal secretions. Copper when present in excess, the free excess copper ions cause damage to cellular components (USEPA 1994; Gotteland et al. 2001). The amount of cellular copper is determined by the intake and outflow of copper ions. Copper in excess amounts not only causes oxidative stress but also damages to DNA and reduces cell proliferation. Symptom of copper toxicity is seen when copper sulfate of more than $1 \mathrm{~g}$ is ingested (Asokan et al. 2021; Sharrett et al. 1982). Copper toxicosis that is resulted from metabolic defect, which is inherited, is classified as primary, and when it is resulted from high intake of copper and low excretion (due to involved pathologic process) is considered as secondary (Harada et al. 2020; Taylor et al. 2020). Copper toxicity could be caused by consumption of foods (Table 3 ) that are acidic and cooked in uncoated copper cookware, or when exposed to excess copper in drinking water, or through other environmental factors (USEPA 1994). Copper toxicity is unusual in healthy people without an inherited copper homeostasis deficiency (Institute of Medicine US 1988; NRC 2000).

\section{Conclusions}

This experimental study was designed to comprehensively understand the leaching potential of copper in water, after water has been stored in a copper containers over a period of time. The copper concentration in the basic raw water is very low. About low and high coper concentrations were found in the samples@12 h and sample@168 h, respectively. It is clear from the experiment study in a normal laboratory conditions, the drinking water quality is slightly deteriorated due to the presence of copper concentration when water is stored in copper containers for several hours. Therefore, immediate precautionary measures can be taken to safeguard the health of people and it is also very important to create a great awareness about water storage and consumption.

Supplementary Information The online version contains supplementary material available at https://doi.org/10.1007/s13201-021-01542-x.

Acknowledgements The authors are thankful to the Chemtex Environmental \& Industrial Hygiene Services for providing necessary facilities to carry out this research work.
Funding No funding is provided for the preparation of manuscript.

\section{Declarations}

Conflict of interest The authors report no financial or nonfinancial conflict of interest. The authors alone are responsible for the content and writing of the paper.

Open Access This article is licensed under a Creative Commons Attribution 4.0 International License, which permits use, sharing, adaptation, distribution and reproduction in any medium or format, as long as you give appropriate credit to the original author(s) and the source, provide a link to the Creative Commons licence, and indicate if changes were made. The images or other third party material in this article are included in the article's Creative Commons licence, unless indicated otherwise in a credit line to the material. If material is not included in the article's Creative Commons licence and your intended use is not permitted by statutory regulation or exceeds the permitted use, you will need to obtain permission directly from the copyright holder. To view a copy of this licence, visit http://creativecommons.org/licenses/by/4.0/.

\section{References}

Abedi Sarvestani R, Aghasi M (2019) Health risk assessment of heavy metals exposure (lead, cadmium, and copper) through drinking water consumption in Kerman city. Iran Environ Earth Sci 78(24):714

Adimalla N, Qian H (2019) Groundwater quality evaluation using water quality index (WQI) for drinking purposes and human health risk (HHR) assessment in an agricultural region of Nanganur, South India. Ecotoxicol Environ Saf 176:153-161

Adimalla N, Qian H (2021) Geospatial distribution and potential noncarcinogenic health risk assessment of nitrate contaminated groundwater in Southern India: a case study. Arch Environ Contam Toxicol 80(1):107-119

Adimalla N, Qian H, Nandan MJ, Hursthouse AS (2020) Potentially toxic elements (PTEs) pollution in surface soils in a typical urban region of south India: an application of health risk assessment and distribution pattern. Ecotox Environ Safe 203:111055

Adkison LR (2012) 10-renal, gastrointestinal, and hepatic disorders. In: Adkison LR (ed) Elsevier's integrated review genetics, 2nd edn. Saunders, Philadelphia, W.B, pp 177-191

APHA (2012) Standard method for the examination of water and wastewater, 19th edn. American Public Association, Washington (DC)

Araya M, McGoldrick MC, Klevay LM, Strain JJ, Robson P, Nielsen F, Olivares M, Pizarro F, Johnson L, Poirier KA (2001) Determination of an acute no-observed-adverse-effect level (NOAEL) for copper in water. Regul Toxicol Pharmacol 34(2):137-145

Araya M, Chen B, Klevay LM, Strain JJ, Johnson L, Robson P, Shi W, Nielsen F, Zhu H, Olivares M, Pizarro F, Haber LT (2003) Confirmation of an acute no-observed-adverse-effect and low-observedadverse-effect level for copper in bottled drinking water in a multisite international study. Regul Toxicol Pharmacol 38(3):389-399

Asokan K, Vivekanand PA, Muniraj S (2021) An eco-friendly method to remove copper ion from drinking water by using homemade bio-adsorbent in tip-tea-bag. Mater Today Proc 36:883-885

Bashir F, Irfan M, Ahmad T, Iqbal J, Butt MT, Sadef Y, Umbreen M, Shaikh IA, Moniruzzaman M (2021) Efficient utilization of low cost agro materials for incorporation of copper nanoparticles to 
scrutinize their antibacterial properties in drinking water. Environ Technol Innov 21:101228

Buchanan SD, Diseker RA, Sinks T, Olson DR, Daniel J, Flodman T (1994) Copper in drinking water, Nebraska, 1994. Int J Occup Environ Health 5(4):256-261

Casper J (2017) Copper toxicity and self-evaluation. Retrieved April 20, 2017, from Nutritional Balancing.org: http://nutritionalbala ncing.org/center/htma/science/articles/copper-toxicity.php

Collins JF (2014) Copper. In: Ross AC, Caballero B, Cousins RJ, Tucker KL, Ziegler TR (eds) Modern nutrition in health and disease, 11th edn. Lippincott Williams \& Wilkins, Baltimore, MD, pp 206-216

Dong W, Zhang Y, Quan X (2020) Health risk assessment of heavy metals and pesticides: a case study in the main drinking water source in Dalian, China. Chemosphere 242:125113

Fewtrell L, Kay D, Jones F, Baker A, Mowat A (1996) Copper in drinking water-an investigation into possible health effects. Public Health 110(3):175-177

Fitzgerald DJ (1995) Copper guidelines values for drinking water: reviews in need of review? Regul Toxicol Pharmacol 21:001-003

Fitzgerald DJ (1998) Safety guidelines for copper in water. Am J Clin Nutr 67(suppl):1098S-1102S

Florence TM et al (1992) Toxicity of lipid-soluble copper (II) complexes to the marine diatom Nitzschia closterium: amelioration by humic substances. Water Res 26(9):1187-1193

Gomaa H, Shenashen MA, Elbaz A, Yamaguchi H, Abdelmottaleb M, El-Safty SA (2021) Mesoscopic engineering materials for visual detection and selective removal of copper ions from drinking and waste water sources. J Hazard Mater 406:124314

Gotteland M, Araya M, Pizarro F, Olivares M (2001) Effect of acute copper exposure on gastrointestinal permeability in healthy volunteers. Dig Dis Sci 46(9):1909-1914

Harada M, Honma Y, Yoshizumi T, Kumamoto K, Oe S, Harada N, Tanimoto A, Yabuki K, Karasuyama T, Yoneda A, Shibata M (2020) Idiopathic copper toxicosis: is abnormal copper metabolism a primary cause of this disease? Med Mol Morphol 53(1):50-55

Harris ZL (2019) Chapter 9-ceruloplasmin. In: Kerkar N, Roberts EA (eds) Clinical and translational perspectives on WILSON DISEASE. Academic Press, pp 77-84

Institute of Medicine (US) (1998) Standing Committee on the Scientific Evaluation of Dietary Reference Intakes. "Uses of dietary reference intakes." Dietary Reference Intakes for Thiamin, Riboflavin, Niacin, Vitamin B6, Folate, Vitamin B12, Pantothenic Acid, Biotin, and Choline. National Academies Press (US)

IPCS (1998) IPCS Workshop on Issues in Cancer Risk Assessment, Hannover, Germany, IPCS/98.x

IPCS (1999) Environmental health criteria for copper, vol 200. WHO

Kulkarni A, Sharma VK (2017) Wilson's disease. In: Quah SR (ed) International encyclopedia of public health, 2nd edn. Academic Press, Oxford, pp 424-433

Lytle DA, Wahman DG, Schock MR, Nadagouda MN, Harmon S, Webster K, Botkins J (2019) Georgeite: a rare copper mineral with important drinking water implications. Chem Eng J 355:1-10

National Research Council (2000) Inquiry and the national science educationstandards. Washington, DC: National Academy Press
Physical Science Study Committee (1960) Physics. Heath. National Institutes of Health 2018, Boston. https://www.nih.gov/researchtraining/medical-research-initiatives

Prohaska JR (2012) Copper. In: Erdman JW, Macdonald IA, Zeisel SH (eds) Present knowledge in nutrition, 10th edn. Wiley-Blackwell, Washington, DC, pp 540-553

Sharma AK, Priya Kaith BS, Singh A, Isha Vipula, Chandel K (2020) Enzymatic construction of quinine derivative of dextrin/ PVA based hybrid gel film for the simultaneous detection and removal of copper and lead ions in real water samples. Chem Eng J 382:122891

Sharrett AR, Carter AP, Orheimt RM, Feinleib M (1982) Daily intake of lead, cadmium, copper, and zinc from drinking water: the seattle study of trace metal exposure. Environ Res 28(2):456-475

Subba Rao N, Sunitha B, Adimalla N, Chaudhary M (2020) Quality criteria for groundwater use from a rural part of Wanaparthy District, Telangana State, India, through ionic spatial distribution (ISD), entropy water quality index (EWQI) and principal component analysis (PCA). Environ Geochem Health 42(2):579-599

Taiwo AM, Aigbodion CO, Ojekunle OZ, Akinhanmi TF (2020) Health risk assessment of metals in selected drinks from Abeokuta, Southwestern Nigeria. Biol Trace Elem Res 197(2):694-707

Taylor AA, Tsuji JS, Garry MR, McArdle ME, Goodfellow WL, Adams WJ, Menzie CA (2020) Critical review of exposure and effects: implications for setting regulatory health criteria for ingested copper. Environ Manage 65(1):131-159

Underwood EJ (1977) Copper. Trace elements in human and animal nutrition, 4th edn. Academic Press, New York, pp 56-108

USEPA (1985) National primary drinking water regulations, environmental protection agency. 40 CFR Part 141. Fed Reg 50:49767

USEPA (1991) Maximum contaminant level goals and national primary drinking water regulations for lead and copper; final rule, 40 CFR Parts 141 and 142. Fed Reg 56:110

USEPA (1994) Drinking water: maximum contaminant level goal and national primary drinking water regulation for lead and copper. Fed Regist 59(125):33860-33864

WHO (1993) Guidelines for drinking water quality. Vol 1. Recommendations, 2nd edn. World Health Organization, Geneva, Switzerland

WHO (1998) Guidelines for drinking-water quality, 2nd ed. Addendum to vol. 2, health criteria and other supporting information. WHO/ EOS/98-1

Zhang Q, Xu P, Qian H (2020) Groundwater quality assessment using improved water quality index (WQI) and human health risk (HHR) evaluation in a semi-arid region of northwest China. Expo Health 12:487-500. https://doi.org/10.1007/s12403-020-00345-w

Zhang Q, Qian H, Xu P, Li W, Feng W, Liu R (2021) Effect of hydrogeological conditions on groundwater nitrate pollution and human health risk assessment of nitrate in Jiaokou Irrigation District. J Clean Prod 298:126783

Publisher's Note Springer Nature remains neutral with regard to jurisdictional claims in published maps and institutional affiliations. 